\title{
THE SIGNIFICANCE OF EXPOSITION AND DEVELOPING OSCILATIONS IN CTP AND Conventional Plate Making Processes
}

\author{
Cigula, T.; Mahovic PoljaceK, S. \& Gojo, M.
}

Abstract: In this study the quality level of the CtP (Computer to Plate) and conventional printing plates was observed. These two processes were by analysing the differences of the coverage values caused by oscillations in exposure and developing time. These two parameters were selected in the printing plate making process because it was assumed that they have large impact on printing plate quality. The results have showed that changes in exposure of the printing plate and differences in chemical developing time have a great influence on coverage values and consequently, on the printing plate quality. It is also visible that selected oscillations cause similar changes in CtP and conventional plate making process. From these results one can concluded that although the CtP is computer controlled process it requires frequent control and adjustment of observed parameters as well as conventional process.

Key words: CtP plates, conventional plates, exposure, chemical developing, quality control
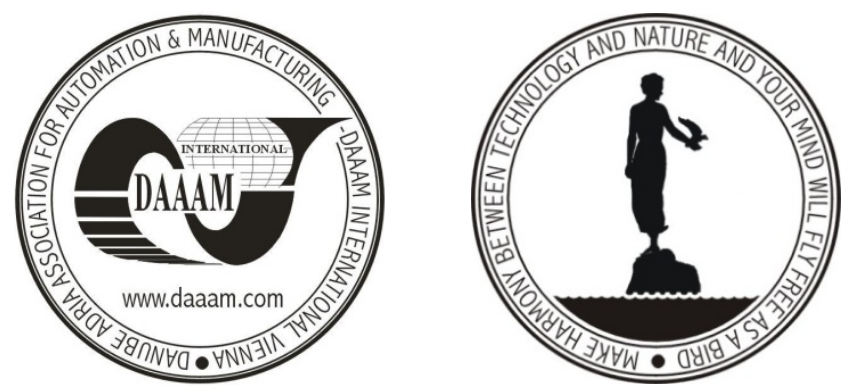

Authors' data: Cigula, T[omislav]; Dr. Mahovic Poljacek, S[anja]; Prof.Gojo,M[iroslav], University of Zagreb, Faculty of Graphic Arts, Getaldiceva 2, 10000, Zagreb, HR, tomislav.cigula@grf.hr, sanja.mahovic.poljacek@grf.hr, miroslav.gojo@grf.hr

This Publication has to be referred as: Cigula, T[omislav]; Mahovic Poljacek, S[anja] \& Gojo, M[iroslav] (2008). The Significance of Exposition and Developing Oscilations in CTP and Conventional Plate Making Processes, Chapter 20 in DAAAM International Scientific Book 2008, pp. 229-238, B. Katalinic (Ed.), Published by DAAAM International, ISBN 978-3-901509-66-7, ISSN 1726-9687, Vienna, Austria

DOI: $10.2507 /$ daaam.scibook.2008.20 